\title{
Proposal for recording bonds convertible to raw materials
}

\author{
Robert Ranosz $z^{1,1}$ \\ ${ }^{1}$ AGH University, Department of Economics and Management in Industry, Al. Mickiewicza 30 30-059 Kraków, Poland
}

\begin{abstract}
In view of the fact that the proposed method of recording is a conceptual model, the author of the publication intends to draw further considerations in that direction. The article consists of four parts. The introduction hereto outlines the objectives of this study. The second part of the publication presents the methodology, on the basis of which (according to the author) it shall be possible to record the bonds convertible to raw materials. The third part of the article presents a hypothetical issue of the said debt instrument with an option on the part of the issuer. The last part of the work presents the conclusions of the study. The article ends with a bibliography, based on which this article has been written.
\end{abstract}

\section{Introduction}

Over the last few years the Polishmining industry has been subject to constant change, mainly aimed at improving its economic and financial situation [1]. The improvement of this situation also entails the necessity to acquire cheapest capital for financing the business activities of mining companies. Mining companies have increased their share in equities in all sources of financing, and intend to benefit from the more flexible forms of debt, such as long-term corporate bonds [2]. The continuously growing bond market creates new opportunities for investors. Undoubtedly, the possibility of having additional options embedded in bonds contributes to the reduction of the significant cost of capital for mining companies [3]. Bonds convertible to raw materials are new financial solutions proposed by the author of this publication to finance mining investments. Apart from the elements related to the valuation of such debt instruments and presenting a possibility of its application, including benefits for both parties of a contract, the method of its recording also constitutes an important element. This article presents the proposal of recording bonds convertible to raw materials for the issuer as well. From the accounting point of view, bonds convertible to raw materials and shares are relatively similar. The main distinctive feature is the time of debt conversion. In the case of conversion into shares, the investor becomes the owner of a part of the company, whereas the issuer increases its equity. In case of bonds convertible to raw materials, the abovedescribed situation does not take place. At the time of conversion, some part of the issuer's debt is eliminated in exchange for the provided raw material (for which the issuer shall not receive any funds). The author of the publication suggests treating such reduction of debt by the bondholder in exchange for the delivered raw material as debt redemption, which shall increase other operating revenues. Since the revenue is not of a physical nature (no funds are credited to the bank account of a mine), it is essential to make relevant adjustments in the financial flows. Therefore, the objective of this article is to propose a model of recording bonds convertible to raw materials.

\section{Methodology}

As mentioned in the introduction here to, the methodologies of recording bonds convertible to shares and raw materials shall be similar, yet not identical. In this publication the author does not compare the records of these two different debt instruments with an embedded option, but focuses on the type of book entry for the subject matter hereof. The basic differences between the records of these two different debt instruments are recognised initially and mean that in the case of bonds convertible to shares, we deal with the capital element, whereas in the case of bonds convertible to raw materials, we deal with the value of a derivative instrument.

In compliance with the regulation of the Minister of Finance of 12 December 2001 on detailed principles of recognition, valuation methods, the scope of disclosure, and the way of presenting financial instruments, $\S 13 \mathrm{sec}$. 3 , first, it is necessary to estimate a fair value of the derivative instrument, and then, on the basis thereof, to estimate the value of the obligation element [4]. The value of the derivative instrument may be estimated by one of three available methods. They include the continuous method applying the Black-Scholes model,

${ }^{1}$ Corresponding author: rranosz@agh.edu.pl 
and discreet methods, such as bi- and trinominal models. In the further part of the publication, the value was defined as $W R_{o}$. The $W R_{o}$ value constitutes a discount on the bond (obligation). It is connected with distinguishing the obligation item; in such a case, the bond is considered the financial instrument issued with the discount, which in the initial recognition is equal to $W R_{o}$. After establishing $W R_{o}$, it is possible to determine the obligation element of the bond convertible to raw materials in compliance with correlation (1).

$$
E_{z}=(N * I)-W R_{o}
$$

Where:

$E_{z}$ - obligation element

$N$ - nominal value of the bond

$I$ - number of issued bonds

The next step, in accordance with the amortised cost method, is to define the value of the Internal Return Rate (IRR). The value is established by correlation (2).

$$
E_{z}=\sum_{i=1}^{n} \frac{O_{i}}{(1+I R R)^{i}}+\frac{N^{*} I}{(1+I R R)^{n}}
$$

Where:

$O_{i}$ - interest (coupon) on the nominal value of the bond in the period " $i$ "

The interest rate is calculated in accordance with formula (3) in the event when the conversion is performed in a given year.

$$
O_{i}=N * r * \frac{y}{12} * I_{z}
$$

Where:

$r$ - value of the bond's coupon (interest on the bond)

$y$ - month in which the conversion was performed

$I_{z}$ - number of bonds converted into raw materials

The interest is charged as of the beginning of the year and considered interest-bearing liabilities. At the time of the conversion it is necessary to write off some part of the interest payable towards the converted bonds (in accordance with formula (3)). The interest has been accrued, but shall not be paid.

After determining the initial parameters, within the subsequent years of tenor of bonds convertible to raw materials, it is essential to adjust the obligation element by the $I R R$ value and interest, following correlation (4):

$$
S E_{z(i)}=\left(E_{z(i-1)} *(1+I R R)\right)-O_{i}
$$

Where:

$S E_{z(i)}$ - adjusted obligation element

$E_{z(i-1)}$ - obligation element from the previous period ( $\left.i-1\right)$

Formula (4) assumes that the obligation element is adjusted in the first year after the issue of the bond. In the following years, $E_{z(i-1)}$ shall be equal to $S E_{z(i-1)}$.
It should also be mentioned that at the time of the conversion, the $I R R$ value must be adjusted depending on the month in which the conversion is performed: i.e. $\operatorname{IRR}^{*}(y / 12)$.

In accordance with the assumptions for convertible bonds, the financial cost is defined by correlation (5). The value has been created based on $[5,6]$.

$$
K F_{i}=S E_{z(i)}-E_{z(i-1)}+O_{i}
$$

Where:

$K F_{i}$ - financial costs in the period " $i$ "

Similarly to the previous case, in the subsequent years $E_{z(i-1)}$ shall be equal to $S E_{z(i-1)}$. The difference in the financial cost in a given period and the interest accrued for the same period shall be the value decreasing the discount on the bond (obligation). The value is established by correlation (6).

$$
Z O_{i}=K F_{i}-O_{i}
$$

Where:

$\mathrm{ZO}_{i}$ - value decreasing the discount on the bond (obligation)

Table 1. Initial assumptions for the issue of shares convertible to raw materials.

\begin{tabular}{|c|c|}
\hline $\begin{array}{c}\text { Number of years for which the bond } \\
\text { convertible to raw mate rials is iss ued. }\end{array}$ & \\
\hline Nominal value of the bond & PLN 1,000 \\
\hline Number of issued bonds & 2,000 \\
\hline Conversion factor & 20 \\
\hline Conversion price & PLN 50 \\
\hline Market price of a raw material at the time of \\
conversion & PLN 65 \\
\hline Nominal value of the issue & PLN \\
\hline Coupon (interest) of the bond & $6 \% 000$ \\
\hline Standard deviation of the base instrument & $25 \%$ \\
\hline Unit cost of excavation of Mg of the material & PLN 35 \\
\hline
\end{tabular}

At this point it should be mentioned that the $Z O_{i}$ value shall be calculated at the time of the conversion in accordance with correlation (7). Therefore, the value decreasing the discount on the bond shall be defined by the $S Z O_{i}$ value and shall constitute an undepreciated discount on the bond subject to conversion as for the date thereof.

$$
S Z O_{i}=\frac{I_{z}}{I} \sum_{i=1}^{n} Z O_{i}
$$

It is suggested that at the time of the debt to raw material conversion, instead of creating a supplementary capital the same as with bonds convertible to shares, the financial revenues should be created the same way as the supplementary capital. The value of the financial 
revenues should be established in accordance with formula (8). Created based on $[5,6]$.

$$
P F=W O Z+\left(W R_{o} \frac{I_{z}}{I}\right)-\left(I_{z} * N\right)
$$

Where:

$P F$ - financial revenues

$W O Z$ - value of bonds converted to raw materials

The $W O Z$ value is estimated based on formula (9):

$$
W O Z=\frac{I_{z}}{I} * E_{z(i)}\left(1+\operatorname{IRR} \frac{y}{12}\right)
$$

Similarly to the previous case, in the subsequent years $E_{z(i)}$ shall be equal to $S E_{z(i)}$. At the time of the debt to raw material conversion, no share capital is established as in the case of bonds convertible to shares. It is suggested that instead of share capital in the case of bonds convertible to raw materials, the financial revenues should be created in the event when the value of the converted debt is higher than the cost of the delivered raw materials or the financial costs in the opposite case (the value of the supplied inventory is higher than the value of the converted debt).

\section{Example of recording convertible to raw materials}

bonds

On the basis of the methodology presented in chapter 2 hereof, a model way of recording bonds convertible to raw materials for the issuer has been presented. To perform correct calculations and recordings, it is essential to first assume the initial values defining a given issue. The initial conditions for the issue of bonds convertible to raw materials are presented in table 1 . In the calculation example it was assumed that no transactional costs occurred.

On the basis of the above-mentioned correlations, the value $I R R=37.57 \%$ has been estimated in accordance with the amortised cost method. Following the discreet model (trinominal), the market value of the options embedded in the bond convertible to raw materials has been estimated. The value is PLN 792,629.73. On the basis of the nominal value, the value of the obligation element in the amount of PLN 1,207,370.27(PLN2,000,000 - PLN $792,629.73$ ) has been obtained. In this case, the recording is in line with table 2 .

Table 2. Initial recognition of the issue of bonds convertible to raw materials.

\begin{tabular}{|c|c|c|}
\hline Name of account & Dt [PLN] & Ct [PLN] \\
\hline Current account & $2,000,000$ & \\
\hline $\begin{array}{c}\text { Bond obligations } \\
\text { (nominal value) }\end{array}$ & & $2,000,000$ \\
\hline $\begin{array}{c}\text { Obligations - bonds } \\
\text { (discounts) }\end{array}$ & $792,629.73$ & \\
\hline Revaluation reserve & & $792,629.73$ \\
\hline
\end{tabular}

After the first year of tenor of the bond convertible to raw materials, the bondholder decided not to convert debt into raw material. The recording at the end of the first year is in table 3 .

Table 3. Recognition of bonds on the recording accounts after the first year of tenor of the bond convertible to raw material.

\begin{tabular}{|c|c|c|}
\hline Name of account & Dt [PLN] & Ct [PLN] \\
\hline Current account & & 120,000 \\
\hline Financial costs & $453,637.22$ & $120,000.00$ \\
\hline $\begin{array}{c}\text { Short-term liabilities } \\
\text { (interest) }\end{array}$ & $120,000.00$ & $333,637.22$ \\
\hline $\begin{array}{c}\text { Obligations - bonds } \\
\text { (discounts) }\end{array}$ & & \\
\hline
\end{tabular}

Table 4. Calculation of the interest and financial costs for the period up to the conversion time

\begin{tabular}{|c|c|c|}
\hline Name of account & Dt [PLN] & Ct $\{$ PLN] \\
\hline Financial costs & $434,244.38$ & \\
\hline $\begin{array}{c}\text { Short-term liabilities } \\
\text { (interest) }\end{array}$ & & $90,000.00$ \\
\hline $\begin{array}{c}\text { Obligations - bonds } \\
\text { (discounts) }\end{array}$ & & $344,244.38$ \\
\hline
\end{tabular}

After 9 months, in the second year of the bonds' tenor, the investor decided to convert debt into raw material. The number of bonds has been established at the level of 1,000 bonds. First, the interest and financial costs for the period of up to 9 months were calculated. The recording of this event is in table 4 .

Table 5. Conversion of debt into raw material, including delivery of raw material to the recipient.

\begin{tabular}{|c|c|c|}
\hline Name of account & Dt [PLN] & Ct [PLN] \\
\hline $\begin{array}{c}\text { Bond obligations } \\
\text { (nominal value) }\end{array}$ & $1,000,000.00$ & \\
\hline Financial revenues & & $300,000.00$ \\
\hline Revaluation reserve & $396,314.86$ & $383,940.80$ \\
\hline Financial revenues & & \\
\hline $\begin{array}{c}\text { Short-term liabilities } \\
\text { (interest) }\end{array}$ & $45,000.00$ & $57,374.06$ \\
\hline $\begin{array}{c}\text { Obligations - bonds } \\
\text { (discounts) }\end{array}$ & & 700,000 \\
\hline Inventory & &
\end{tabular}

The next step was the debt to raw material conversion. In this part, the delivery of the raw material to the recipient (investor) was assumed. The recording of the conversion of the bonds into raw materials is in table 5 .

Table 6. Calculation of the interest and financial costs for the period after the conversion time

\begin{tabular}{|c|c|c|}
\hline Name of account & Dt [PLN] & Ct [PLN] \\
\hline Financial costs & $72,374.06$ & $15,000.00$ \\
\hline $\begin{array}{c}\text { Short-term liabilities } \\
\text { (interest) }\end{array}$ & & \\
\hline $\begin{array}{c}\text { Obligations - bonds } \\
\text { (discounts) }\end{array}$ & $57,374.06$ & \\
\hline
\end{tabular}

In the next step the interest and financial cost have been calculated until the end of the year (after conversion). The recording entry of this event is in table 6 . 
In the last step the investor redeemed the bonds. The event is presented in table 7 .

Table 7. Redemption of bonds

\begin{tabular}{|c|c|c|}
\hline Name of account & Dt [PLN] & Ct [PLN] \\
\hline $\begin{array}{c}\text { Bond obligations } \\
\text { (nominal value) }\end{array}$ & $1,000,000$ & \\
\hline $\begin{array}{c}\text { Short-term liabilities } \\
\text { (interest) }\end{array}$ & 60,000 & \\
\hline Current account & & $1,060,000$ \\
\hline
\end{tabular}

In the last step the remaining part of the revaluation reserve was reclassified to the issuer's financial revenues. The activity is presented in table 8 .

Table 8. Redemption of bonds

\begin{tabular}{|c|c|c|}
\hline Name of account & Dt [PLN] & Ct [PLN] \\
\hline Revaluation reserve & $396,314.86$ & \\
\hline Financial revenues & & $396,314.86$ \\
\hline
\end{tabular}

\section{Summary}

The objective of this article is to propose the recording of bonds convertible to raw materials. The assumed goal has been accomplished in this study. The proposal of recording the subject matter hereof is similar to the recording of bonds convertible to shares. However, the events are not identical. In the case of bonds convertible to shares, the investor - at the time of the conversion - becomes a shareholder in the company that issued the debt instrument, whereas in the case of bonds convertible to raw materials, in exchange for the debt redemption, the bondholder receives the raw material at the conversion price, which is usually lower at the time of the conversion than the market price of the raw material.

\section{Bibliography}

1. R. Magda, S. Głodzik, J. Jasiewicz, T. Woźny, Arch. of Min. Sci. 54, 1 (2009)

2. M. Sierpińska, P. Bąk, Arch. of Min. 57, 4 (2012)

3. R. Ranosz, Arch. of Min. 59, 1 (2014)

4. RFI - Regulation of the Minister of Finance of 12 December 2001 on detailed principles of recognition, valuation methods, the scope of disclosure and the way of presenting financial instruments

5. G.K. Świderska, Sprawozdania finansowe bez tajemnic. (Difin Warsaw 2003 p. 8-13)

6. M. Frendzel, Rachunkowość instrumentów finansowych $w$ świetle regulacji krajowych I międzynarodowych.

(Stowarzyszenie księgowych w Polsce Warsaw 2010) 